Rok XIV (2019) | 2 (28) | s. 265-276

https://doi.org/10.12797/LV.14.2019.28.18

Piotr Żmigrodzki ๑

Instytut Języka Polskiego Polskiej Akademii Nauk, Kraków

piotr.zmigrodzk@ijp.pan.pl

\title{
PROFESOR ZENON KLEMENSIEWICZ JAKO REDAKTOR „JEZZYKA POLSKIEGO”
}

Słowa klucze: Zenon Klemensiewicz, historia polskiego językoznawstwa, Towarzystwo Miłośników Języka Polskiego, czasopismo „Język Polski”

Keywords: Zenon Klemensiewicz, history of Polish linguistics, The Society of Friends of the Polish Language, the "Język Polski" journal

\section{Wprowadzenie}

Życiorys i osiągnięcia naukowe Zenona Klemensiewicza przedstawiano już wiele razy, przeważnie z okazji kolejnych okrągłych rocznic jego tragicznej śmierci (por. m.in. Pisarkowa 1972; Pisarek 1979, 2009; Majkowska, Fiałek 2011), zawsze jednak koncentrowano się na jego dorobku w obrębie poszczególnych dziedzin, które zgłębiał: gramatyki, historii języka polskiego, stylistyki, metodyki nauczania, pedagogiki językowej itp., na aspektach jego życia prywatnego czy też na wspomnieniach osobistych. Jego działalności jako przewodniczącego Zarządu Głównego Towarzystwa Miłośników Języka Polskiego i redaktora „Języka Polskiego” poświęcano co najwyżej wzmiankę i kilka ogólnikowych stwierdzeń. Tymczasem ta aktywność autora Historii języka polskiego trwała ponad 10 lat, od końca roku 1958 do śmierci w roku 1969, zatem stosunkowo długo. Była poprzedzona długoletnią obecnością na łamach „Języka Polskiego” w roli autora, współpracownika, a potem członka komitetu redakcyjnego. W tekście niniejszym chciałbym przedstawić kilka uwag na temat roli Z. Klemensiewicza w historii czasopisma "Język Polski”, opartych na analizie 
materiałów ogólnodostępnych: dawnych roczników pisma, wspomnień i innych świadectw osób Klemensiewiczowi współczesnych.

Fakt, że po śmierci Kazimierza Nitscha (26 września 1958 r.) funkcje przewodniczącego Zarządu Głównego TMJP i redaktora „Języka Polskiego” powierzono Klemensiewiczowi, chyba dla nikogo nie okazał się zaskoczeniem. Był bowiem Klemensiewicz związany z Towarzystwem od samych jego początków. Już w 1922 r. wybrano go do Zarządu Głównego, w którym objął na wiele lat funkcję sekretarza, a w roku 1950 został zastępcą przewodniczącego. Także w roku 1922 debiutował jako autor w „Języku Polskim” i szybko stał się aktywnym współpracownikiem pisma, a potem członkiem komitetu redakcyjnego. To, że Klemensiewicz w przyszłości zajmie jego pozycję, przewidywał również sam Nitsch i - jak świadczą dokumenty - nie był z tej perspektywy zbyt zadowolony. W opublikowanej niedawno (Skarżyński, Smułkowa 2018) korespondencji autora Dialektów języka polskiego z Antoniną Obrębską-Jabłońską znalazłem na ten temat dwie wzmianki. Pisał Nitsch 24 maja 1948 r. (por. ibid.: 119):

[...] po mojej śmierci dla JP redaktorem z natury rzeczy zostanie Zenon, ale ze względu na staranność winien być Safar; dobry byłby i Urbańczyk, ale czy będzie w Krakowie?

a niespełna rok później, 7 maja 1949 r., zaznaczył (ibid.: 212):

Pani jest cudowną korektorką, a raczej powinna Pani zostać redaktorką jakiegoś pisma, bo mało tak do tego dostosowanych. Ale niestety, nie JP, bo tu po mnie oczywiście będzie Zenon, nie mający ani połowy tego poglądu w dokładności. I Urbańczyk gorszy od Pani, choć [-] od Zenona, a Safarewicz bardzo staranny, ale za mało samodzielny.

Jeśli wierzyć Stanisławowi Urbańczykowi (1999: 427), wielki Redaktor w jego i innych osób obecności wprost przedstawiał swoją wolę, aby to właśnie Urbańczyk został jego następcą. Ten jednak był, jak się okazało, dopiero trzeci w kolejce do stanowiska redaktora "Języka Polskiego" i objął je ćwierć wieku później, w styczniu 1983 r., po rezygnacji Safarewicza, który przejął i prezesurę w Towarzystwie, i czasopismo po śmierci bohatera tego artykułu. Ostatecznie więc po śmierci Nitscha przewodniczącym Zarządu Głównego TMJP i redaktorem „Języka Polskiego” został Klemensiewicz. Jego nazwisko jako redaktora pojawiło się pierwszy raz na stronie redakcyjnej w zeszycie pierwszym za rok 1959 (rocznika XXXIX czasopisma). Ostatnim zredagowanym przezeń zeszytem był zeszyt drugi za rok 1969 (XLIX rocznika), tak więc pełnił swą funkcję przez 10 lat z okładem i przygotował łącznie 52 zeszyty czasopisma. 


\section{Zenon Klemensiewicz w „Języku Polskim”. Droga do pozycji redaktora}

Historia współpracy Klemensiewicza z „Językiem Polskim” zaczyna się wcześnie, bo w roku 1922. Wtedy opublikował on recenzję pracy Stanisława Szobera Zasady nauczania języka polskiego $w$ zakresie szkoły powszechnej i gimnazjum niższego. Analiza danych bibliograficznych zgromadzonych przez Krystynę Pisarkową i Annę Kałkowską (1982) pozwala stwierdzić, że jest to w ogóle debiut Klemensiewicza jako autora publikacji drukowanych ${ }^{1}$. W sumie do roku 1969 ukazało się w „Języku Polskim", jak udało mi się ustalić ${ }^{2}, 139$ pozycji podpisanych nazwiskiem lub inicjałami późniejszego autora Historii języka polskiego. Z publikacji tych 25 pozycji przypada na okres do 1939 r., 78 - na czas od końca II wojny światowej do śmierci Nitscha, pozostałych 36 - na lata redaktorstwa Klemensiewicza w „Języku Polskim”. Reprezentują one różne gatunki naukowych i publicystycznych wypowiedzi. Klasycznych artykułów naukowych naliczyłem 31 (albo 32, jeśli za artykuł naukowy uznamy projekt prawideł poprawnej wymowy polskiej). Największą grupę, bo 48 pozycji, stanowią drobne artykuliki na temat najnowszych zjawisk językowych, odpowiedzi na pytania czytelników itp., 21 pozycji to dopiski do innych artykułów, 20 - recenzje, 10 - sprawozdania, pozostałe to wystąpienia jubileuszowe i nekrologi. Właśnie nekrolog przedwcześnie zmarłego składniowca Henryka Misza (zresztą nader zwięzły) był ostatnią publikacją Klemensiewicza w „Języku Polskim” (1968, z. 5).

W rozbiciu na lata szczegółowe zestawienie wygląda następująco:

\begin{tabular}{lccccccc}
\multicolumn{1}{c}{ Okres } & Artykuły & Recenzje & $\begin{array}{c}\text { Sprawo- } \\
\text { zdania }\end{array}$ & Dopiski & Drobiazgi & Inne & Suma \\
\hline $1922-1939$ & 6 & 7 & 9 & 1 & 1 & 1 & 25 \\
$1945-1958$ & 13 & 13 & 1 & 13 & 37 & 1 & 78 \\
$1959-1969$ & 13 & 1 & 0 & 7 & 10 & 5 & 36 \\
Łącznie & 32 & 21 & 10 & 21 & 48 & 7 & 139
\end{tabular}

Przedstawiony rozkład aktywności Klemensiewicza w kolejnych trzech okresach w „Języku Polskim” odzwierciedla zmieniający się jego status w samej redakcji i w pewnym sensie również w środowisku naukowym. Najpierw był luźnym współpracownikiem, piszącym głównie o sprawach nauczania języka polskiego i ortografii,

1 W wymienionej bibliografii recenzje są umieszczone po artykułach, w związku z czym wspomniana recenzja wymieniona jest jako czwarta w kolejności. Jednak porównanie dat wydawniczych czasopism wskazuje na pierwszeństwo chronologiczne recenzji książki Szobera w dorobku Klemensiewicza.

2 Ustalenia opieram na analizie bibliografii pierwszych 50 roczników czasopisma (Zeszyt jubileuszowy). Nie odpowiada ona ściśle liczbie odwołań do nazwiska Klemensiewicz w indeksie tej pracy, co jest spowodowane zarówno pewnymi odkrytymi przeze mnie błędami jej redaktorów, jak i sposobem notowania niektórych prac cyklicznych. 
choć już w roku 1927 pomieścił dwuczęściowe studium o języku Wyspiańskiego. W roku 1935 przyjęto go do komitetu redakcyjnego chyba w miejsce zmarłego Jana Rozwadowskiego, ale jego pozycja uległa zmianie dopiero po wojnie. Włączał się wówczas w działalność redakcyjną bardzo intensywnie, o czym świadczy przede wszystkim liczba tzw. drobiazgów, jakie w tym okresie zamieścił. Głównie były to odpowiedzi na pytania czytelników, komentarze do dawniejszych cudzych i własnych artykułów itp. Takich materiałów było z kolei mniej w okresie trzecim, kiedy to najwyraźniej znalazł innych ludzi do wypełniania działów „petitowych”, jak się je określało do niedawna w gronie redakcyjnym (ze względu na to, iż działy te drukowane były właśnie petitem, czyli czcionką o rozmiarze 8 pkt, a więc mniejszym niż artykuły naukowe, drukowane garmondem (10 pkt)). Będzie jeszcze o tych współpracownikach Klemensiewicza mowa.

Analiza tematyki artykułów Klemensiewicza nie jest przedmiotem tego opracowania, warto jednak wspomnieć, że właśnie w okresie przedredaktorskim ogłosił on w periodyku kilka istotnych tekstów, które na trwałe weszły do bibliografii lingwistycznej, jak np. wspomniany projekt prawideł poprawnej wymowy polskiej (JP XIII, 1928: 4-12, 33-40), ważny jako świadectwo epoki tekst Pan i obywatel (JP XXVI, 1946: 33-42), a także Tytuły i nazwy zawodowe kobiet $w$ świetle teorii i praktyki (JP XXXVII, 1957: 101-119), artykuł, do którego do dzisiaj sięgają chętnie przedstawiciele (i przedstawicielki) językoznawstwa feministycznego. Drukował także artykuły będące szkicowymi czy wstępnymi wersjami fragmentów Historii języka polskiego, zamieścił również istotny polemiczny głos na temat rodzącej się na przełomie lat 40. i 50. XX w. koncepcji Słownika języka polskiego Witolda Doroszewskiego (JP XXXII, 1952: 49-66). To właśnie tekstem Klemensiewicza, zatytułowanym Miłośnictwo języka w dziejach polszczyzny (JP XXV, 1945: 1-7), zaczyna się pierwszy powojenny zeszyt czasopisma (był to odczyt wygłoszony na pierwszym walnym zgromadzeniu odrodzonego Towarzystwa w maju 1945 r.). Z przywoływanej już korespondencji Nitscha i Obrębskiej-Jabłońskiej wiadomo, że brał czynny udział w pracach redakcji, związanych z opiniowaniem artykułów, rozstrzyganiem sporów ${ }^{3}$ itd. Zanim więc objął funkcję redaktora, zapisał już piękną kartę jako autor i współtwórca historii czasopisma.

3 Tych nie było mało, a to ze względu na porywczy charakter Nitscha, warto tu wspomnieć np. o absurdalnym konflikcie z Witoldem Doroszewskim w sprawie artykuliku na temat wyrażenia akademickie rekolekcje zamknięte, o konflikcie z Witoldem Taszyckim, dotyczącym kwestii pochodzenia polskiego języka literackiego czy wreszcie z Mikołajem Rudnickim, zakończonym publikacją przez niego pojednawczego oświadczenia na łamach pisma. 


\section{"Język Polski" pod redakcją Zenona Klemensiewicza}

Pora zatem przystąpić do zasadniczej części artykułu, czyli przedstawienia aktywności Klemensiewicza w roli redaktora czasopisma. Rozpatrywać ją należy na tle ówczesnej sytuacji polskiego językoznawstwa, które u progu lat 6o. XX w., podobnie jak i cała nauka i kultura polska, zaczynało się wydobywać ze stanu pewnego zakonserwowania teoretyczno-metodologicznego, w jaki popadło $w$ okresie powojennym i stalinowskim, otwierać na nowe trendy, jakie już od dłuższego czasu, nawet kilku dziesięcioleci, zadomowiły się w życiu umysłowym Europy i świata: przede wszystkim strukturalizm, a później także, w ograniczonym stopniu - generatywizm, pragmatykę czy lingwistykę tekstu. Niewątpliwie ze śmiercią Nitscha zamknęła się pewna epoka w dziejach czasopisma, ale śmierć ta współtowarzyszyła przemianom, jakie się dokonywały na zewnątrz redakcji. Nowy redaktor starał się tym wyzwaniom sprostać, co niewątpliwie warto zauważyć i docenić.

Zwrócić więc trzeba uwagę przede wszystkim na zmiany w komitecie redakcyjnym, jakich dokonał. W momencie śmierci Nitscha składał się on z następujących osób: Z. Klemensiewicz, Tadeusz Lehr-Spławiński, A. Obrębska-Jabłońska, Jan Safarewicz, Andrzej Siudut, S. Urbańczyk. Wszyscy byli związani z Krakowem, oprócz Obrębskiej-Jabłońskiej, pracującej na Uniwersytecie Warszawskim. Już z początkiem 1959 r. komitet powiększa się o sześć osób. Dochodzą Ewa Ostrowska (wcześniej już współpracująca z redakcją), Maria Dłuska, a także czterej uczeni spoza Krakowa: Karol Dejna i Stefan Hrabec z Uniwersytetu Łódzkiego, Władysław Kuraszkiewicz z Poznania i Stanisław Rospond z Wrocławia. Następnie w roku 1962 dołącza K. Pisarkowa, a w 1966 r. Franciszek Sławski (na miejsce zmarłego rok wcześniej Lehra-Spławińskiego). Za czasów Klemensiewicza komitet redakcyjny ma więc skład najliczniejszy w historii; nie wiadomo natomiast, jaki był rzeczywisty udział wymienionych osób w pracach redakcyjnych. Urbańczyk (1999: 397) twierdzi, że Klemensiewicz „wprowadził jedynowładztwo” i nie zwoływał posiedzeń redakcyjnych, a o wszystkich sprawach decydował sam. Wiadomo jednak skądinąd, że najbardziej zaufanymi jego współpracowniczkami w tym okresie były K. Pisarkowa i E. Ostrowska. Ta ostatnia od 1966 r. występuje w stopce redakcyjnej jako „sekretarz naukowy”. Wcześniej takiej funkcji w redakcji oficjalnie nie było, choć z korespondencji Nitscha i Obrębskiej-Jabłońskiej wiadomo, iż zadania przynależne sekretarzowi wykonywał w latach 40. i 50. A. Siudut. Ostrowska przejęła je od niego najprawdopodobniej już w 1961 r., gdy wyjechał na dłużej do Szwecji ${ }^{4}$. Funkcja sekretarza naukowego pozostała już na trwałe w komitecie redakcyjnym czasopisma; po śmierci Ostrowskiej (1977) pełnił ją Marian Kucała (1978-1988), potem przez wiele lat Krystyna Kowalik (1989-2010), przejściowo w 2009 r. Anna Tyrpa, a od 2011 r. sekretarzem jest Monika

Wspomina o tym Zofia Kurzowa w nekrologu Ostrowskiej (Kurzowa 1978). 
Buława ${ }^{5}$. W okresie redaktorstwa Klemensiewicza ważną rolę jako współpracownicy redakcji odgrywali również dwaj młodsi językoznawcy, Walery Pisarek i M. Kucała. Do komitetu redakcyjnego wówczas nie należeli ${ }^{6}$, ale regularnie publikowali w czasopiśmie, zaczynając od odpowiedzi na pytania czytelników. Obaj debiutowali w tej roli w 1961 r., zamieszczając swoje notki, podpisywane rzadziej pełnym imieniem i nazwiskiem, częściej inicjałami. Dla Pisarka był to rzeczywisty debiut na łamach czasopisma, Kucała już wcześniej drukował w „Języku Polskim” artykuły. Z nich dwóch oczywiście bliżej z Klemensiewiczem związany był Pisarek, jego podwładny w Ośrodku Badań Prasoznawczych i w pewnym sensie uczeń (choć promotorem jego rozprawy doktorskiej była córka Klemensiewicza, Irena Bajerowa). Właśnie dzięki współpracy Klemensiewicza z Pisarkiem pojawiać się zaczęły w "Języku Polskim” artykuły dotyczące poprawności języka w prasie (nie tylko - jak wcześniej przez lata - doraźne notki piętnujące pojedyncze lapsusy, ale bardziej dogłębne opracowania), a także teksty, które z dzisiejszego punktu widzenia zaliczylibyśmy do szeroko pojętej pragmalingwistyki (np. artykuł pod mało informatywnym tytułem $O$ języku stowarzyszonym (JP XLIV, 1964: 220-231) w którym Pisarek chyba pierwszy raz w polskiej lingwistyce zwracał uwagę na konieczność odnoszenia sensu wypowiedzi do kontekstu i konsytuacji oraz wprowadzał termin zawiadomienie) ${ }^{7}$. Z drugiej strony wiadomo, że z aktywnej pracy redakcyjnej wycofali się wówczas A. Obrębska-Jabłońska oraz A. Siudut.

Po omówieniu spraw osobowych pora wskazać, jakie inne zmiany zaszły w ,Języku Polskim" w czasach Klemensiewicza, a co kontynuowano. Na pewno zmienił się ogólny sposób redagowania pisma, co wynikało z różnicy osobowości między oboma uczonymi: autorem Historii języka polskiego i jego poprzednikiem. Z przekazów wynika, że Nitsch miał charakter choleryczny, w czasopiśmie zaś dość mocno eksponował własną osobę, co manifestowało się przede wszystkim w licznych dopiskach i uwagach do publikowanych artykułów, a także polemikach, czasem gwałtownych, $\mathrm{z}$ publikacjami $\mathrm{w}$ innych czasopismach, a nawet $\mathrm{z}$ drukowanymi $\mathrm{w}$, Języku Polskim”. Klemensiewicz przeciwnie, we wspomnieniach jawi się jako „koturnowy” (choć zdaniem Pisarkowej (1972) ta „koturnowość” była wystudiowana na użytek obcych), a nawet wyniosły, w każdym razie zdystansowany. Obserwujemy więc w latach 6o. mniej niż dawniej jego dopisków do cudzych artykułów, jeżeli już się pojawiają, da się w nich zauważyć jednak nieco inny stosunek do autorów niż Nitschowski. Bardzo typowy jest tu dopisek do artykułu Wesołowskiej Język fantastyczny w utworach Stanistawa Lema (1963):

5 Szczegółowe informacje o składzie komitetu redakcyjnego „Języka Polskiego” i jego członkach zamieszczono w artykule: Żmigrodzki 2013.

6 Kucała stał się jego członkiem w roku 1972, a Pisarek - dopiero w 2005.

7 Warto zauważyć, że po śmierci Klemensiewicza Pisarek na długie lata w zasadzie zniknął z łamów „Języka Polskiego”, por. na ten temat Żmigrodzki 2018. 
Ogłaszamy powyższy artykuł, ponieważ porusza interesujące ze stanowiska językoznawczego szczegóły, a w swojej końcowej części ankietowej poucza o postawie młodego (w tej jednostronności słabość zabiegu badawczego) czytelnika. Może wywoła on uwagi dyskusyjne odbiorców naszego czasopisma i uzupełni ocenę wyrazotwórczych dokonań S. Lema, które w świetle wywodów autorki wydają się zdobyczą językowo-stylistyczną, co - zdaniem Redakcji - musi budzić niejakie wątpliwości (Klemensiewicz 1963: 27).

Manifestuje się tu postawa redaktora i linia redakcyjna, odkrywana również w innych tekstach publikowanych w czasopiśmie w latach 6o. XX w., mianowicie świadomość konieczności uwzględnienia najnowszych metod, technik i odkryć językoznawczych, ale jednocześnie chęć ich własnej oceny czy też wyrażenia własnego stosunku (redaktora lub w ogóle „redakcji”) do nich, a także pewien paternalizm czy też protekcjonalizm w stosunku do czytelników i również w pewnym stopniu do autorów. Świetnie to widać na innym przykładzie - gramatyki generatywnej, w owym czasie teorii absolutnie dominującej jako nowy trend w światowej lingwistyce. W 1965 r. ukazał się w "Języku Polskim” artykuł Roberta Rothsteina, prezentujący jej zasady w sposób szczegółowy i w tonie raczej aprobatywnym (JP XLV, 1965: 195-208). Potem opublikowano jeszcze dwa artykuły: Witolda Mańczaka (JP XLVII, 1967: 37-49), będący krytyką przedstawionej teorii generatywizmu tyleż zdecydowaną, ile nieuwzględniającą w ogóle stanowiska teoretycznego Chomsky'ego i jego zwolenników, a także rzeczowy artykuł Adama Heinza (JP XLVII, 1967: 49-57), wyjaśniający różnice między podejściem tradycyjnym (= młodogramatycznym), strukturalistycznym i generatywistycznym do systemu językowego.

Zamyka dyskusję jakże charakterystyczna nota podpisana „Redakcja” (JP XLVII, 1967: 57-58):

Wedle postanowień statutu ma Towarzystwo Miłośników Języka Polskiego krzewić przywiązanie do mowy ojczystej oparte także „na zrozumieniu zjawisk językowych w ogóle”. Tym się tłumaczy, dlaczego, pragnąc poinformować o nowych tendencjach badawczych współczesnej lingwistyki, co zwłaszcza dla czytelników uprawiających studia w tym zakresie może mieć wartość, ogłosiła redakcja artykuł R.A. Rothsteina [...]. Jak każde nowatorstwo, także to z dziedziny językoznawczej grzeszy samo zbytnią pewnością siebie, a spotyka się z krytyką częściowo uzasadnioną, częściowo przekraczającą granice słuszności. Aby zainteresowany czytelnik mógł uzyskać pełniejszy obraz tej polemicznej postawy, zgodziła się redakcja - nie bez niejakich oporów z uwagi na zbyt specjalistyczny charakter roztrząsań - na ogłoszenie artykułu doc. W. Mańczaka [...]. Pragnąc zaś przedstawić czytelnikom w całej rozciągłości dzisiejszy stan wiedzy w tej dziedzinie, redakcja zwróciła się do doc. A. Heinza o artykuł informacyjny i tym artykułem [...] dyskusję zamyka.

Aby dopełnić kwestię obecności gramatyki generatywnej na łamach „Języka Polskiego" w latach 60. XX w., wspomnę jeszcze o krytycznym omówieniu Aspects of the Theory of Syntax Chomsky'ego pióra Krystyny i Walerego Pisarków na łamach 
czasopisma (JP XLVI, 1966: 234-241). Dzięki takim pracom wiedza o najnowszych trendach $\mathrm{w}$ lingwistyce światowej przenikała do polskiego (i polskojęzycznego) czytelnika.

Problematyka składniowa w nowszym, strukturalistycznym wydaniu zagościła zresztą na dobre na łamach "Języka Polskiego" w omawianym okresie, ukazywały się ważne teksty badaczy takich jak K. Pisarkowa, A. Kałkowska, Danuta Wesołowska, Anna Wierzbicka (idzie o jej dwa znane wczesne artykuły: O metodach opisu szyku wyrazów, JP XLIV, 1964: 14-26 i Czy istnieja zdania bezpodmiotowe, JP XLVI, 1966: 177-196), Jadwiga Twardzikowa, Henryk Misz. Był pionierski artykuł Marii Kniagininowej Próba zastosowania metod statystycznych $w$ badaniach stylistyczno-składniowych (JP XLII, 1962: 92-116). Z prac niezajmujących się składnią, ale pozostających $\mathrm{w}$ aktualnych wówczas nurtach metodologicznych wymienić można istotną rozprawę A. Heinza Fleksja a derywacja (JP XLI, 1961: 343-354), Stanisława Jodłowskiego Substantywizacja przymiotników jako jeden z elementów procesu rozwojowego języka (JP XLVI, 1964: 7-14), Zuzanny Topolińskiej O kategoriach gramatycznych polskiego imperatiwu (JP XLVI, 1966: 167-173) i Kategoria osoby w języku polskim (JP XLVII, 1967: 88-95), Romana Laskowskiego i Henryka Wróbla Użycie paradygmatu $w$ funkcji formantu słowotwórczego we współczesnej polszczyźnie (JP XLIV, 1964: 214-220). Z prac klasycznych dla polskiego językoznawstwa przypomnieć warto także dwa teksty Jacka Fisiaka dotyczące kontaktów międzyjęzykowych i zapożyczeń: Zjawisko depluralizacji niektórych rzeczowników angielskich zapożyczonych przez język polski (JP XLI, 1961: 138-139) i Złożony kontakt językowy $w$ procesie zapożyczania z języka angielskiego do polskiego (JP XLII, 1962: 86-94).

Wykuwały się także pod Klemensiewiczowską pieczą na łamach „Języka Polskiego" podstawy polskiego prasoznawstwa, zrazu jako refleksja nad poprawnością języka w prasie. To wiąże się z ówczesną aktywnością redaktora jako konsultanta, a potem przewodniczącego rady naukowej w Ośrodku Badań Prasoznawczych przy RSW „Prasa”. Oprócz doniosłego metodologicznie wspomnianego już tekstu W. Pisarka $O$ języku stowarzyszonym był jeszcze drugi - W trosce o język prasy (JP XLII, 1962: 161-164), w którym przedstawiono program badań nad tą odmianą polszczyzny, wykraczających poza czystą lapsologię, mamy także już bardziej szczegółowe studium tego autora pt. Rzeczowniki w reportażach $i$ wiadomościach prasowych (JP XLIX, 1969: 37-43), również artykuł M. Kniagininowej Struktury opisowe - znamienna cecha stylu dziennikarskiego (JP XLIII, 1963: 148-157). To jeszcze niewiele w porównaniu z prasoznawczymi opracowaniami, jakie się ukazywały później, ale można z dużą dozą pewności ocenić, że gdyby nie Klemensiewicz, prace te mogłyby się nie ukazać na łamach czasopisma, a nawet mogłyby nie powstać w ogóle.

Obecność tych publikacji na łamach pisma, a także obecność wielu innych prac z zakresu poprawności językowej, bez wątpienia wynika z misji Towarzystwa, ale bezpośrednio wiąże się również z realizowanym szczególnie intensywnie w owym okresie przez Klemensiewicza programem - jak to on sam nazwał - pedagogiki ję- 
zykowej, ogłoszonym zresztą na łamach „Języka Polskiego” niedługo po wojnie. Jak wówczas pisał Klemensiewicz (1947: 45):

Ideałem wychowawczym pedagoga językowego będzie człowiek władający mową ojczystą z całą świadomością i wysiłkiem, by ona oddała wiernie pełnię jego życia duchowego; który ocenia też wartość estetycznego działania mowy; który wobec nieuchronnych wątpliwości i wahań potrafi się zdobyć na świadomy, krytyczny wybór; który dąży do zdobycia pewnych przekonań językowych. Ideałem wychowawczym jest, żeby grono takich świadomych używców ${ }^{8}$ języka rozszerzało się na masy narodowe $[\ldots]$.

W działalności Klemensiewicza i w jego polityce redakcyjnej jako redaktora „Języka Polskiego" znajdujemy liczne przykłady realizacji tego programu, a najdobitniejszym tego wyrazem jest artykuł (wcześniej przedstawiony, jak wiele Klemensiewiczowskich prac, w formie odczytu w Towarzystwie) pt. Higiena językowego obcowania (Klemensiewicz 1965). W tym zaledwie ośmiostronicowym tekście autor zawarł wszystko, co dzisiaj w wersji rozwiniętej i w różnych mutacjach upowszechniają autorzy związani z Zespołem Etyki Słowa Rady Języka Polskiego PAN: należy dbać o grzeczność i uczciwość w komunikacji, zachowywać szacunek dla rozmówcy, unikać ostrych i brutalnych sformułowań, nie używać wulgaryzmów, nie promować ich w komunikacji publicznej ani nawet w utworach artystycznych, bo ma to zgubny wpływ na nawyki językowe ludzi, zwłaszcza młodych. Jak konkludował autor (ibid.: 8):

Środkami administracyjnych represji niewiele się wskóra, choć zapewne w niektórych sytuacjach i one mogą być potrzebne i pożyteczne. Ale istota zadania leży w wychowaniu człowieka, którego postawa w tej dziedzinie zachowywania się musi ulec zmianie. To jest zadanie i obowiązek szkoły i rozmaitych ośrodków kulturalnego oddziaływania.

Koncentrowałem się dotąd na tym, co nowego pojawiło się na łamach czasopisma za redaktorstwa i (prawdopodobnie) za sprawą Klemensiewicza. Rzecz oczywista, zachowały swoje miejsce obszary problematyki dominujące za czasów Nitscha, to znaczy przede wszystkim historia języka polskiego, gramatyka historyczna (tu zaznaczają się przede wszystkim prace autorów krakowskich związanych z opracowywanymi w PAN słownikami, a także Klemensiewiczowskie wyimki z Historii ję$z y k a$ polskiego) oraz dialektologia (kontynuowano np. tradycję druku oryginalnych tekstów gwarowych z komentarzem językoznawczym, pisali też autorzy związani

8 Zwróćmy marginesowo uwagę na rzadki leksem używca. Pojawia się on jeszcze w kilku innych tekstach Klemensiewicza drukowanych w „Języku Polskim”. W słowniku pod red. W. Doroszewskiego jest on zanotowany jako przestarzały, z dwoma cytatami: z rozprawy Tadeusza Sinki i z Rozmów o języku Doroszewskiego, w którym przytoczenie tego wyrazu stanowi zresztą najprawdopodobniej złośliwy przytyk pod adresem autora Historii języka polskiego. 
z warszawskimi pracowniami słownikowymi, jak Hanna Popowska-Taborska czy Janusz Siatkowski, sam zaś redaktor opublikował pionierski artykuł Niektóre właściwości syntaktyczne chłopskiej mowy potocznej (JP XLVI, 1966: 245-255), przekraczający granice dialektologii w kierunku badań nad składnią języka mówionego w ogóle). Reprezentowane były też artykuły o języku autorów (por. wcześniej przywołany artykuł Wesołowskiej o Lemie czy pracę Jerzego Bartmińskiego pt. Sposoby użytkowania gwary w utworach Adolfa Dygasińskiego (JP XLIV, 1962: 284-280)). Dużo miejsca zajmował oczywiście dział poprawnościowy; systematycznie prowadzono dział recenzji i sprawozdań. Teksty z zakresu onomastyki pojawiały się w niewielkiej liczbie i raczej przyczynkowe. Onomaści mieli już wówczas swoje czasopismo „Onomastica” (ukazujące się od 1955 r.), poza tym zaważyły na tej sytuacji prawdopodobnie również nie najlepsze stosunki osobiste między Witoldem Taszyckim a Klemensiewiczem (a wcześniej Nitschem) ${ }^{9}$. Tylko S. Rospond, członek komitetu redakcyjnego, opublikował kilka poważniejszych rozpraw (np. O leksykografii nazewniczej, JP XLIX, 1969: 50-57).

Pisząc o osiągnięciach Klemensiewicza jako redaktora, nie sposób nie wspomnieć o tym, jak rósł nakład „Języka Polskiego” w latach 6o. W roku śmierci Nitscha (1958) wynosił on 5,5 tys. egzemplarzy, w roku 1961 - już 7,2 tys., w roku 1968 przekroczył 10 tys., osiągając już wysokość bliską swojemu historycznemu maksimum (11,6 tys. egzemplarzy w połowie lat 7o. ${ }^{10}$. Dziś wiemy, że popyt ten był wykreowany sztucznie przez prenumeratę periodyku w szkołach i innych instytucjach (wydających na to środki publiczne), ale przecież powiększanie zasięgu tej prenumeraty musiało być efektem także zabiegów samego redaktora, który pełnił ważne funkcje w Związku Nauczycielstwa Polskiego (od 1961 r. był jego wiceprezesem). Pewnie oddziaływał tu również osobisty czar uczonego, któremu jego powierzchowność i wypracowany sposób bycia oraz wykładania przysparzały zwolenników wśród szerokich kręgów słuchaczy. Gdy jeździł po kraju z odczytami, przybywały na nie bardzo liczne grupy ludzi, np. z opublikowanego sprawozdania TMJP (JP XLVI, 1966: 318) wynika, że w Rybniku 10 listopada 1965 r. jego wykładu słuchało ponad tysiąc osób. Czasopismo było więc w tamtych latach szeroko dostępne i zapewne miało szeroki odbiór społeczny; jego treści były pod tym względem w pewnym stopniu do tego dostosowane, a w każdym razie widać choćby z przytoczonych przeze mnie wcześniej cytatów, że redaktor o to dostosowanie zabiegał. Ale odbywało się to bez uszczerbku dla jego poziomu naukowego, ukazywały się bowiem artykuły naukowe czołowych polskich badaczy, odwołujące się do aktualnej wiedzy i aktualnych w naszym środowisku lingwistycznym trendów metodologicznych.

9 Także i później materiały z dziedziny onomastyki nieczęsto się w „Języku Polskim” pojawiały; sytuacja ta utrzymuje się w zasadzie do dziś.

10 Nakład „konkurencyjnego” „Poradnika Językowego” w tym okresie niewiele przekraczał 2 tys. egzemplarzy. 


\section{Podsumowanie}

Z. Klemensiewicz objął prezesurę Towarzystwa Miłośników Języka Polskiego i funkcję redaktora "Języka Polskiego" w wieku ponad 67 lat, a więc już w końcowym okresie swojej drogi życiowej ${ }^{11}$, tragicznie, jak wiemy, przerwanej. Mimo to działał $\mathrm{z}$ energią, łącząc tę funkcję z rozlicznymi innymi. Rozbudował zespół redakcyjny, wprowadzając doń uczonych $\mathrm{z}$ innych ośrodków, pozyskał młodych współpracowników, rozszerzył zakres tematyki podejmowanej w piśmie, zbliżając go do problematyki, jaką zajmowali się wówczas młodsi uczeni w swoich pracowniach w Polsce i na świecie. Doprowadził do niemal dwukrotnego zwiększenia nakładu pisma i tym samym przychodów Towarzystwa. Niewątpliwie uczynił wiele, aby świetność "Języka Polskiego" po śmierci jego twórcy Kazimierza Nitscha utrzymać i pielęgnować, dostosowując do zmieniających się warunków zewnętrznych. Czy można było uczynić więcej? Możliwe, ale nie nam dzisiaj to oceniać. Ważne jest, że kiedy go zabrakło, kiedy śmierć - jak napisano w żałobnym adresie we wkładce do „Języka Polskiego" 12 - „wybrała samolot za swoje narzędzie, nie mogąc Profesora zniszczyć inaczej, gdy w ciągu pół roku pokonał zwycięsko dwie ciężkie choroby", osierocone czasopismo pozostało w stanie na tyle dobrym, że następcy mogli je przejąć i prowadzić dalej ku kolejnym sukcesom i utrwaleniu jego miejsca w historii polskiego językoznawstwa.

\section{Literatura}

Klemensiewicz Z., 1947, Poprawność i pedagogika językowa, „Język Polski” XXVII, s. 38-46.

Klemensiewicz Z., 1963, Dopisek do: Wesołowska 1963, „Język Polski” XLIII, s. 27.

Klemensiewicz Z., 1965, Higiena językowego obcowania, „Język Polski” XLV, s. 1-8.

Kurzowa Z., 1978, Ewa Ostrowska (5 maja 1907-16 listopada 1977), „Pamiętnik Literacki” LXIX, z. 2, s. 331-335.

Majkowska R., FiaŁek E. (red.), 2011, Zenon Klemensiewicz 1891-1969. Materiały z posiedzenia naukowego $w$ dniu 19 czerwca 2009 r., Kraków.

Pisarek W., 1979, Językoznawcze dziedzictwo Zenona Klemensiewicza, „Język Polski” LIX, S. 321-329.

Pisarek W., 2009, Zenon Klemensiewicz - w czterdziestolecie śmierci, „LingVaria” nr 2 (8), S. $179-199$.

Pisarkowa K., 1972, Zenon Klemensiewicz (1891-1969). Materialy i szkice do portretu, „Pamiętnik Literacki” LXIII, z. 3, s. 184-206.

11 Podobnie zresztą działo się z jego następcami: Safarewiczem, Urbańczykiem, Kucałą, Pisarkową, którzy w momencie obejmowania stanowiska redaktora byli już w okolicach siedemdziesiątego roku życia. 
Pisarkowa K., KaŁKowska A., 1982, Bibliografia prac Z. Klemensiewicza, wydanych w latach 1922-1976, [w:] Z. Klemensiewicz, Składnia, stylistyka, pedagogika językowa. Wybór prac, red. A. Kałkowska, Warszawa, s. 861-887.

SkARŻyński M., SmuŁKowa E. (oprac.), 2018, Materiały do dziejów polskiego językoznawstwa III. Korespondencja Kazimierza Nitscha i Antoniny Obrębskiej-Jabłońskiej 1925-1958, cz. 2: 1946-1958, „Biblioteka LingVariów”, t. 26, Kraków.

Urbańczy K S., 1999, Z miłości do wiedzy. Wspomnienia, oprac. A. Gorzkowski, Kraków.

WesoŁowska D., 1963, Język fantastyczny w utworach Stanisława Lema, „Język Polski” XLIII, s. 13-27.

Zeszyt jubileuszowy: Język Polski. Zeszyt jubileuszowy. Bibliografia zawartości roczników 1-50, Kraków 1971.

ŻMigrodzki P., 2013, Ludzie „Języka Polskiego”, „Język Polski” XCIII, s. 2-9.

Żmigrodzki P., 2018, Profesor Walery Pisarek i język polski, „Język Polski” XCVIII, z. 1, s. 113-119, [on-line:] http://dx.doi.org/10.31286/JP.98.1.9.

\section{Professor Zenon Klemensiewicz as the Editor of "Język Polski" Summary}

The paper presents the activity and achievements of Professor Zenon Klemensiewicz as the editor of the "Język Polski" journal ('The Polish Language'), the official publication of The Society of Friends of the Polish Language (Towarzystwo Miłośników Języka Polskiego). Klemensiewicz became the editor in the end of 1958, and performed his duties until his death in a plane crash, on April 2, 1969. The author identifies the most important of Klemensiewicz's achievements at the position of the editor: the extension of the editorial board of the journal, the introduction of new authors and numerous papers representing the most recent (in the 196os) linguistic trends, such as structural and generative linguistics, text linguistics, press discourse analysis, as well as the increase of the circulation of the journal and its importance for the Polish linguistic community as well as for other groups of its readers. 